\title{
Noble gas and halogen systematics of fluids within diamond coats from Canada and Africa.
}

Johnson, L.H. ${ }^{1}$, Burgess, R. ${ }^{1}$, Turner, G. ${ }^{1}$, and Milledge, H.J. ${ }^{2}$.

' Dept. of Earth Sciences, University of Manchester, Oxford Rd., Manchester, UK

${ }^{2}$ Dept. of Geological Sciences, University College London, Gower St., London, UK

Since the discovery of the $\mathrm{H}_{2} \mathrm{O}-\mathrm{CO}_{3}{ }^{2-}-\mathrm{K}_{2} \mathrm{O}$ rich fluid inclusions within coated stones, much work has been devoted to characterising these fluids and extrapolating these findings to the mantle in which diamonds grow. African diamonds previously studied have ${ }^{40} \mathrm{Ar}-\mathrm{K}$ ratios corresponding to meaningless old ages $(\sim 6 \mathrm{Ga})$. The excess ${ }^{40} \mathrm{Ar} *$ is trapped in the fluid inclusions and correlates well with chlorine, values of ${ }^{40} \mathrm{Ar} * / \mathrm{Cl}$ are consistently $\sim 8.5 \times 10^{-4}$ molar. This study presents data on 15 diamonds from the North West Territories (NWT) of Canada and compares them with the relatively well known diamonds from Jwaneng, Botswana and Zaire.

The results suggest that a very different fluid component was involved during diamond formation beneath the Slave Craton.

\section{Introduction}

An extension of the ${ }^{40} \mathrm{Ar}-{ }^{39} \mathrm{Ar}$ stepped heating method enables noble gas and halogen $(\mathrm{Br}, \mathrm{Cl}$ and $\mathrm{I})$ contents of fluid inclusions within diamonds to be measured. Nuclear irradiation converts the potassium and halogen species to stable noble gas isotopes which are then released upon step heating of the sample and measured simultaneously using a mass spectrometer. A double vacuum furnace reaches $2150^{\circ} \mathrm{C}$ (above the graphitisation temperature of diamond, $\sim 2000^{\circ} \mathrm{C}$ ).

The study compares the halogen and noble gas geochemistry of the fluids trapped within coated stones all believed to be composed of a cubic habit core surrounded by an octahedral habit coat rich in fluid inclusions.

In this study 15 coats from 4 pipes in the North West Territories (NWT) of Canada are studied; Fox (4), Grizzly (2), Leslie (4) and Koala (5). Average sample weight was $2.4 \mathrm{mg}$, comparable to the stones used by Turner et al. (1990). The system blanks are small enough to allow step heating of the diamonds, through 6 steps from $900^{\circ} \mathrm{C}$ to $2150^{\circ} \mathrm{C}$. The observed release pattern for all isotopes shows two major release peaks (Fig. 1); the first, low temperature release at about $1600^{\circ} \mathrm{C}$. This release previously noted, (Turner et al., 1990; Burgess and Turner, 1995) was these authors suggested, due to decrepitation of inclusions or radiation damage. The main release for these Canadian stones however is often delayed until $2150^{\circ} \mathrm{C}, 100^{\circ}$ above the recognised graphitisation temperature of $2050^{\circ} \mathrm{C}$. This is not mentioned in earlier experiments involving diamond graphitisation; it may be due to inclusion density or size and their effect on the reaction kinetics. It is noted that combustion is complete at $2150^{\circ} \mathrm{C}$ but further experimentation is needed for clarification. In agreement with the work of Turner et al., no major compositional differences exist between the argon released at low temperature and that released at high temperature.

The small sample of Canadian stones in this study have ${ }^{40} \mathrm{Ar} / \mathrm{K}$ ratios corresponding to anomalous ages of $>4.5 \mathrm{Ga}$ due to the presence of excess argon, first recognised by Ozima et al., (1989). The correlation noticed by many co-workers between ${ }^{40} \mathrm{Ar}-\mathrm{K}$ and ${ }^{40} \mathrm{Ar}-\mathrm{Cl}$ is seen again in these Canadian stones. Plotted upon the 'isochron diagram', $\left({ }^{40} \mathrm{Ar} r^{36} \mathrm{Ar}\right)$ against $\left(\mathrm{K}^{36} \mathrm{Ar}\right)$, there is much scatter, in contrast there is a relatively well defined array on a plot of $\left({ }^{40} \mathrm{Ar} /{ }^{36} \mathrm{Ar}\right)$ against $\left(\mathrm{Cl} /{ }^{36} \mathrm{Ar}\right)$ (Fig.2). The gradient of this graph is $\sim 12 \times 10^{-4} \mathrm{M}$, higher than the value of $(8.4 \pm 0.7) \times 10^{-4} \mathrm{M}$ observed previously (Ozima et al., 1989; Turner et al, 1990; Burgess and Turner, 1995) in stones from 
Botswana and Zaire; it is similar to Zaire Stone 4 in the Turner et al. study (1990) with a value of ${ }^{40} \mathrm{Ar} / \mathrm{Cl}$ of $(13 \pm 1) \times 10^{-4} \mathrm{M}$. One notable exception in this study is SLEB/05 which has a value for ${ }^{40} \mathrm{Ar} / \mathrm{Cl}$ of $(5.4 \pm 0.9) \times 10^{-4} \mathrm{M}$.

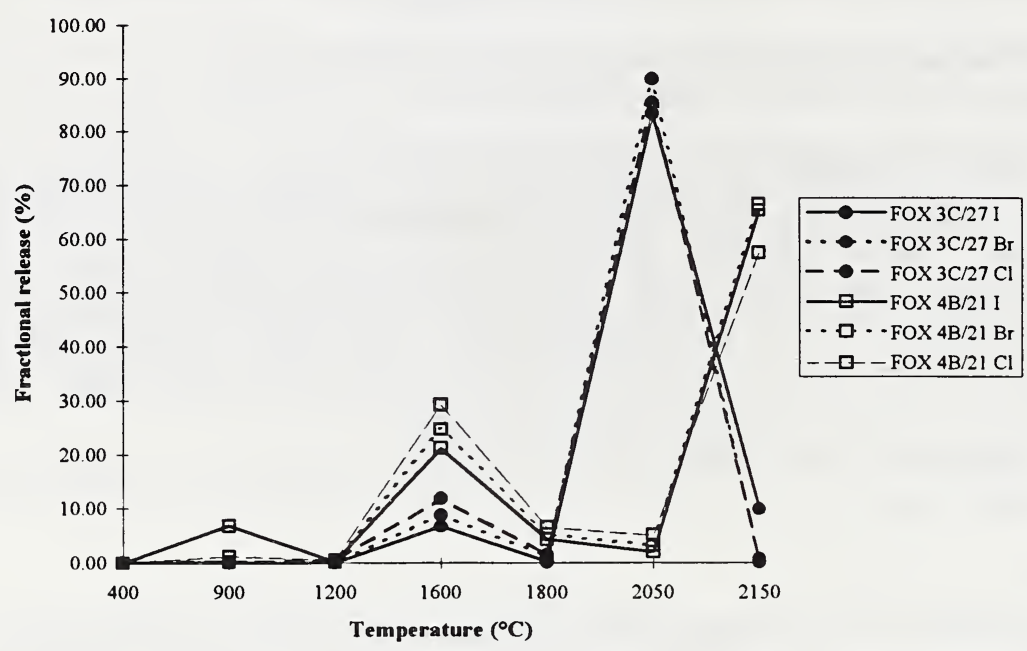

FIG.1 Fractional release of $\mathrm{I}, \mathrm{Br}$ and $\mathrm{Cl}$ against temperature for stepped heating of 2 typical Canadian coated stones (Fox pipe). Halogens are measured as noble gas isotopes $\left({ }^{128} \mathrm{Xe}_{\mathrm{I}},{ }^{80} \mathrm{Kr}_{\mathrm{Br}}\right.$ and $\left.{ }^{38} \mathrm{Ar}_{\mathrm{Cl}}\right)$ produced during nuclear irradiation.

FIG. $2{ }^{40} \mathrm{Ar} /{ }^{36} \mathrm{Ar}$ versus $\mathrm{Cl} /{ }^{36} \mathrm{Ar}$. Fox. squares; Leslie, diamonds; Grizzly, circles; Koala, triangles; open symbols are temperature steps and solid symbols are bulk composition. All ratios are molar.

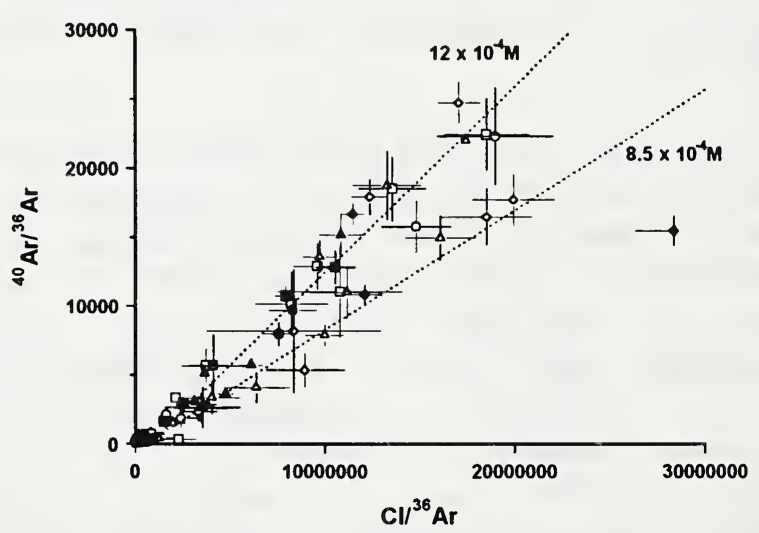

A plot of $\mathrm{I} / \mathrm{Cl}$ against $\mathrm{Br} / \mathrm{Cl}$ (Fig.3) shows most clearly the differences between African and Canadian coated stones. Canadian coats record extreme $\mathrm{Br} / \mathrm{Cl}$ values not previously reported from studies on African coats. High $\mathrm{Br} / \mathrm{Cl}$ in crustal fluids is normally associated with residual bitterns following halite crystallisation or interaction with hydrocarbons in sediments. However in the case of mantle fluids, high $\mathrm{Br} / \mathrm{Cl}$ and $\mathrm{I} / \mathrm{Cl}$ may result from crystallisation of a $\mathrm{Cl}$-bearing phase e.g. apatite or mica, as found as daughter minerals in micro-inclusions in Zaire coats (Gutherie et al., 1991; Schrauder and Navon, 1994). Similarly high $\mathrm{Br} / \mathrm{Cl}$ values, of uncertain origin, have been measured in 'magmatic' fluid inclusions associated with granitic magmas (Burgess and Parsons, 1994; Irwin and Roedder, 1995; Irwin and Reynolds, 1995). 
Further work is currently being undertaken under way to determine the exact nature of these fluids.



FIG 3. $\mathrm{I} / \mathrm{Cl}$ against $\mathrm{Br} / \mathrm{Cl}$. Open squares, Botswana and Zaire stones (Burgess and Turner, 1995); solid squares, Canadian stones (this study). All ratios are molar.

\section{References}

Burgess, R., and Parsons, I., 1994, Argon and halogen geochemistry of hydrothermal fluids in the Loch Ainort granite, Isle of Skye, Scotland: Contributions to Mineralogy and Petrology, v. 115, p. 345-355.

Burgess, R., and Turner, G., 1995, Halogen geochemistry of mantle fluids in diamond: Volatiles in the Earth and Solar System, Pasadena, 1995, AIP Conference Proceedings, p. 91-98.

Gutherie, G. D., Veblen, D. R., Navon, O., and Rossman, G. R., 1991, Submicrometer fluid inclusions in turbid-diamond coats: Earth and Planetary Science Letters, v. 105, p. 1-12.

Irwin, J. J., and Reynolds, J. H., 1995, Multiple stages of fluid trapping in the Stripa granite indicated by laser microprobe analysis of $\mathrm{Cl}, \mathrm{Br}, \mathrm{I}, \mathrm{K}, \mathrm{U}$, and nucleogenic plus radiogenic $\mathrm{Ar}, \mathrm{Kr}$, and $\mathrm{Xe}$ in fluid inclusions: Geochimica et Cosmochimica Acta, v. 59, p.355-369.

Irwin, J. J., and Roedder, J.H., 1995, Diverse origins of fluid in magmatic inclsuions at Bingham (Utah, USA), Butte (Montana, USA), St. Austell (Cornwall, UK) and Ascension Island (midAtlantic, UK), indicated by laser microprobe analysis of $\mathrm{Cl}, \mathrm{K}, \mathrm{Br}, \mathrm{I}, \mathrm{Ba}+\mathrm{Te}, \mathrm{U}, \mathrm{Ar}, \mathrm{Kr}$, and $\mathrm{Xe}$ : Geochimica et Cosmochimica Acta, v. 59, p. 295-312.

Ozima, M., Zashu, S., Takigami, Y., and Turner, G., 1989, Origin of the anomalous 40Ar-39Ar age of Zaire cubic diamonds: excess ${ }^{40} \mathrm{Ar}$ in pristine mantle fluids: Nature, v. 337, p. 226-229.

Schrauder, M., and Navon, O., 1994, Hydrous and carbonatitic mantle fluids in fibrous diamonds from Jwaneng, Botswana: Geochimica et Cosmochimica Acta, v. 58, p. 761-771.

Turner, G., Burgess, R., and Bannon, M., 1990, Volatile-rich mantle fluids inferred from inclusions in diamond and mantle xenoliths: Nature, v. 334, p. 653-655. 